\title{
Transcendental Study on Democracy Concept Formulation in Indonesia and Its Implementation Post Reformasi
}

\author{
Triwahyuningsih, Siti Zuliyah \\ Lecturer of Pancasila and Civic Education Department \\ Ahmad Dahlan University \\ Yogyakarta, Indonesia \\ triwahyuningsih@ppkn.uad.ac.id
}

\begin{abstract}
The aim of the research is elaborating transcendentally about the concept of democracy and its implementation after the amendment of Undang-Undang Dasar (Constitution) 1945. It's a normative research. The material used in this research was coming from primary and secondary legal material by using philosophical, political, and historical approaches. This research conclusion: (1) The Arrangement of democracy concept in Indonesia is a religious democracy, which individual believes in God as it is stated on the preamble of UUD 1945. The preamble was agreed and legalized in the Assembly of Preparatory Committee for Indonesian Independence (PPKI) on 18th of August 1945. That formulation was the agreement amongst founding fathers, becoming the legal basis of state, spiritual soul, and resulting final concept, binding constitutionally in the life of the state. Pancasila has become the state philosophy (Philosopchische Grondslag), state ideology, and Indonesian views of life (Weltanschauung) (2) The implementation of democracy in Indonesia after amendment of UUD 1945 ,which is democratic deliberation as it is stated on the 4th verse, had been hindered by cultural, institutional, and structural obstacles.
\end{abstract}

\section{Keywords—democracy; post reformasi; transendental}

\section{INTRODUCTION}

Positivistic modern science has been in the corridor of modernism-positivism hegemony (The Newtonian Paradigm). Positivistic modern science paradigm with empiricism, objectivism, and rationalism doctrine has started to be questioned by positivistic postmodernism scholar that putting forward the reason behind it to be more open and intact. So to speak, science from the time to time changes usually starting from the changing of paradigm [1].

Science in the transcendental view besides can be elaborated based on Quran and Hadits, it can also be found in Maslahat Mursalah which is an additional legal source based on empirical research (istiqra), obtained from natural phenomena and social behavior with the aim for the benefit of ummah. As stated on Quran ( QS An-Anbiya, verse 107): “And We have not sent you, [O Muhammad], except as a mercy to the worlds," Welfare can be captured clearly by people who have and want to think, although there are differences in understanding the nature of maslahat [2]
Almost all of Indonesian government in power using democracy with different meaning to give constitutional legitimacy upon their built constitutional system. Democracy is the central attention in 1945 Constitution (UUD 1945), so that all of the governments in Indonesia seek to realize the values of democracy by giving interpretation on the meaning of democracy contained in the UUD 1945 [3]. Since Indonesian independence time, democracy have had different terminology from Parliamentary Democracy (1945-1949), Guided Democracy (1959-1967), Democracy of Pancasila (19671998), Transitional Democracy (1998-1999) to Postamendment UUD 1945 democracy. No single formula for the successful implementation of democracy. Each country has its own experience and its own way of practicing democracy. The democratic system cannot be enforced in every country of the world. Democracy should be based on the values of local cultural wisdom, as well as democracy in Indonesia is also inseparable from the culture, and the long history process that has been passed to realize the ideal democracy.

\section{A. The Purpose of Research}

This research aims to explore the transcendental study behind the idea of democracy in Indonesia. Moreover, it also tries to elaborate the practice of democracy after the amendment of the 1945 Constitution.

\section{RESEARCH METHOD}

This is a normative research. The normative research focus on one should behave in accordance with the norms [4]. The material used in this research comes from primary and secondary legal material with philosophistic, yuridical, political and historical approaches.

\section{RESEARCH FINDING AND LEGAL ANALYSIS}

Transcendence according to Roger Garaudy has been interpreted in three perspectives. First, the recognition of human dependence to the Creator. The feeling of being sufficient with themselves and thinking the human as the center of everything is contradicted to transcendental values. Transcendence deal with human instincts, such as greed and lust for power. Secondly, transcendence means recognizing the 
continuity and common proportion between God and man, meaning that transcendence relativizes all power, wealth and knowledge. Third, transcendence means admitting the superiority of some absolute norms that are beyond human power [5].

Transcendental thinking can be seen in religious, spiritual, ethical, and moral values filled with the dynamics and struggles of thought born in a long historical range. Modern science that has been in the corridor of modernist-positivistic hegemony with empirical doctrine, objectivity and rationality began to be questioned by transcendental thinkers who put forward the value and meaning behind it, so that the building of science becomes more open and intact to respond to the problems of life. In this case, transcendental thought begins to elevate irrational and metaphysical (emotion, feelings, intuition, values, personal experience, speculation) morale and spiritual as an integral part of understanding knowledge.

Kuntowijoyo was quoted by Absori interpret transcendence based on the faith of God (Ali Imron: 110) by introducing prophetic science, humanization (ta'muruna bil ma'ruf), liberation (tanhauna anil munkar) and transcendence (tu'minuna billah). In this case, the transcendent element must be the basis of other elements in the development of human knowledge and civilization. The method of science and religion development according to Kuntowijoyo called by prophetic term based on Al-Quran and Sunna is the main base of the whole development of science. The Qur'an and Sunnah are used as the basis for the entire building of the prophetic science, both the science of nature (verse Kauniyah) as the basis of natural laws, humanities (verse Nafsiyah) as the basis of meaning, value and awareness and divinity (verse Qauliyah) the law of God [6].

The transcend verb, from which the transcendental word is taken, is derived from the Latin transcendere which means to climb to / above. The closest meaning from the five definition in Webster's New International Dictionary is transcendental with the meaning of "abstract, metaphysical and "transcending". "Such transcendence in the Prophet Ibrahim tradition is the key to the salvation of modern man. Science, technology and management did bring progress, but failed to bring happiness. Violence is the result of advances in war technology, capital power is caused by the supremacy of science, and the gap is the result of management inequality. All without faith. Transcendental in a spiritual sense will help humanity solve modern problems.

\section{A. The Transcendental Study about Law in Indonesia}

In the development of law in Indonesia, there are some reasons that underlie transcendental view, such as ideology of the Pancasila, the Preamble of UUD 1945 and the Article 29 of UUD 1945. Pancasila is the philosophy of life of the nation state of Indonesia and requires the precepts of God to be the foundation for every other precepts. All the precepts contained in Pancasila are based on the basis of religion and mutual cooperation [7].

The preamble of UUD 1945 is a strong bond (mitsaqon gholidhon) between the founding fathers that become the basis of the state. Indeed, it cannot be changed because it is the spiritual spirit of Indonesia [5]. Pancasila beside as the main element of national values of law and staatsfundamentalnorms, it is also included in the philosophical aspect of Indonesia [8].

The awareness that God is present in the history of the development of Indonesian nationality is explicit in the Preamble to the 1945 Constitution paragraph 3 "By the grace of God Almighty "is a humble and grateful acknowledgment that Indonesian independence can be achieved [9]. The project of the secularization of the people and politics of the archipelago by the colonial regime in fact did not dampen the public role of religion.

From the late nineteenth to early twentieth centuries, "intellectual ulema" and ulema intellectuals (from modernist and traditional society) played an important role in developing modern public sphere in Nusantara. Some of its most important monuments are the Sarekat Dagang Islam (SDI), standing $1908 / 1909$ for economic movement, Muhammadiyah (established 1912) - followed by Nahdatul Ulama (1926) - for educational movement, and Sarekat Islam, established $1911 / 1912$ for political movement. Since the second half of the 1920 s, various organizations of movement from various religious backgrounds began to integrate themselves into Indonesianism by applying the word "Indonesia" in its name. Sarekat Islam, after several renamed names, eventually became the Partai Sjarikat Islam Indonesia (PSII) in 1929.

When independence is achieved, secular intelligence is dominating state leadership, but the weight of the influence of religious and social organizations is too strong to ignore. Compromise attempts were made to maintain harmony between religious and secular party the dialectical results of these two historical party make Indonesia a distinctive "religious secularism" state, in which the secularization process must negotiate with the process of religionization.

\section{B. Transcendental Studies and Formulation of Democracy in Indonesia}

Besides the idea of nationalism, Islamic thought also gives a special pattern to the formulation of ideas of democracy in Indonesia. The idea of democracy is widely accepted among Indonesian Muslims [3]. This acceptance is a resultant of the Islamic modernism movement that developed among Muslims in general who accept democracy as a system of government in accordance with the teachings of Islam.

Similar to nationalist thought, Islamic thought does not accept the idea of democracy as a whole, but develops an idea of democracy based on Islamic teachings. In this position, Islam is essentially in a parallel manner with very anti-Western nationalists who share the idea of a particular democracy. The same attitude is seen in the use of Western science methodology in reconstructing the concepts of democracy. Aidul Fitriciada has argued that the acceptance of democracy based on Islamic teachings has consequences for the system of government based on Islam or an Islamic state. This concept emphasizes the implementation of Sharia as the manifestation of Islamic government system, so that basically democracy is a mechanism to implement the Shari'ah. The mechanism for that is through musyawarah which is a tool for Muslims who are ordered by the Quran in decision making. This musyawarah 
becomes the basic concept of the idea of democracy in Islamic thought.

In addition, the acceptance of democracy is also based on a pragmatic approach of sociological claims that the majority of Indonesians are Muslim. In this position, the idea of Islamic democracy has led to the position of Muslims opposed to the nationality. Despite accepting musywarah as a genuine democratic institution of Indonesia, the nationalists strongly reject the application of Sharia which according to Islamic thought is a consequence of the musyawarah command in the teachings of Islam.

According to Ni'matul Huda, the relation between Islam and democracy are discussed in two approaches, namely normative and empirical approach [10]. On the normative level they question the values of democracy from an Islamic point of view. While on the empirical issue, they analyze the implementation of democracy in political practice and state administration. According to Syafii Ma'arif as quoted by Ni'matul Huda, basically shura is the main political idea in the Qur'an. If the concept of shura is transformed in modern life today, then the political system of democracy is closer to the Qur'ani's political ideals, though it is not necessarily identical to Western democratic practice. Therefore, Syaf'ii Maarif explained that Islam stands fully with the democratic system, although in dealing with certain important issues must be different from the developing democratic system in nonMuslim countries [11].

Islam strongly influences the culture of Indonesia in the field of society and state. In the formulation of Pancasila values alone, the elements of Islam are visible in the concepts of justice, courtesy, society, wisdom, musyawarah and representatives. That the formulation of the fourth verses of Pancasila is very similar to the expression in Arabic which is often used as a proposition and guidance by the scholars, $r a$ 'sul hikmah al-masyurah (base of wisdom is musyawarah) [12].

In its journey, history recorded the first assembly of BPUPKI, 29th May-1st June 1945, with the speech of Soekarno (1st June) raising the term Panca Sila [9]. In this session marked the difference between the two groups of "Islamist" and "nationalist" [13]. We know that in his speech of May 31st, 1945, Ki Bagoes Hadikoesoemo suggested Islam as the basis of the country, since most Indonesian people are Muslims. In contrast to his suggestion on May 31st, 1945 that Islam should be the basis of the state, in the second assembly of BPUPKI (10th-17th July 1945), Ki Bagoes Hadikoesoemo and $\mathrm{Ki}$ Sanusi up to four times suggested that the clause in the fourth paragraph which reads "Belief in Almighty God with the obligation for its Muslim adherents to carry out the Islamic law/Syari'ah" was removed. The proposal of both members was rejected either by the Chairman of BPUPKI. Radjiman Wedyodiningrat as well as by the Chairman of the drafting committee of the Constitution Ir Soekarno.

Therefore the Preparatory Committee for Indonesian Independence (PPKI) did not use the draft Statement of Independence compiled by BPUPKI, but using the draft Preamble of the Constitution prepared by the Nine Committee during the June 22nd, 1945 Reses. On 18th August 1945 morning with the full consent of Islamic figures, they had been able to solve the problem of the clause in the fourth paragraph of the 1945 Constitution, namely "Belief in Almighty God with the obligation for its Muslim adherents to carry out the Islamic law"," to " Belief in the One and Only God ". The phase of "ratification" on August 18, 1945 in the Preparatory Committee Session of Indonesian Independence (PPKI) is what gave birth to the final formula, which is constitutionally binding in the life of the state. Since then Pancasila has become the basis of state philosophy (Philosophische Grondslag), state ideology and worldview (Weltanschauung) Indonesian nation [9].

\section{The realization of democracy in Indonesia after the amendment of the UUD 1945}

The characteristic of law in the Pancasila state implies a law that has a transcendental value towards God Almighty. Pancasila as a way of life has been eroded by law is formalistic, so that the application of the law is not based only on legal certainty of justice [14]. Law that has justice and democratic spirit is addressed to maintain and uphold the dignity of human being [15]. Law is protective to secure the basic rights of the people in which there are several religions, ethnicities, languages and political beliefs. The appreciation of the value of justice and human rights of the Indonesian nation is engraved with gold ink in the Preamble of the UUD 1945, which states that independence is the right of all nations and hence the occupation must be abolished because it is incompatible with humanity and justice. Therefore the law must heed its validity based upon the principles and values of democracy. Feel naïve if we run the practice of isolated law or apart from the prevailing political system, namely Pancasila democracy [16].

Pancasila as the state ideology [17], is the collective view whose formulation lies in the Preamble of the 1945 Constitution, which reads as follows:

..."therefore the independence of Indonesia shall be formulated into a constitution of the Republic of Indonesia which shall be built into a sovereign state based on a belief in the One and Only God, just and civilised humanity, the unity of Indonesia, and democratic life led by wisdom of thoughts in deliberation amongst representatives of the people, and achieving social justice for all the people of Indonesia."

The perfect ideology is the ideals of the life according to God Almighty will for man or nation, and also ideology is a guide and guidance for their personality and social life. For the state, ideology is the source of philosophical views that will radiate its light throughout the State's equipment, throughout the livelihood of society and to all its citizens and citizens. On the other hand Yudi Latif explains that democracy in the mind of Indonesian is not just a technical tool, but also a reflection of the psyche, personality, and national ideals. In Sukarno's view, if democracy is just a technical tool, in essence it is not different from national-socialism (fascism), or dictator of the proletariat, that is just a tool to achieve the desired form the society, whether capitalist, socialistic or otherwise.

That argument also has similarity with Adnan Buyung Nasution idea in which he argues that democracy is not just a way, tool or process, but it is the values or norms that must be animated and reflected the whole process of life in society, 
nation and state. Democracy is not just a criteria in formulating ways or processes to achieve goals, but the goal itself must contain the values of democracy. That is, democracy can never be subordinated under even noble purpose (improvement and achievement of people's welfare [18].

Yudi Latif further explained that our democracy is Indonesian democracy, the democracy mentioned in the fourth precepts of Pancasila, "Democracy led by the wisdom of the representatives of the People" contains several characteristics of the democratic thinking in Indonesia, namely [9]:

- Citizenship (sovereignity of people)

- Deliberation (kinship)

- Wisdom

Citizenship's ideals want to respect the voice of the people in politics by giving way to the great role and influence played by the people in the decision-making process undertaken by the government. The deliberate scheme exudes the will to bring together a united states that can overcome individual and group ideals, as a reflection of the familial spirit of the plurality of Indonesian nationalities by recognizing the existence of "equality in difference"

The ideals of wisdom reflect the ethical orientation, as it is desired by the preamble of the UUD 1945 that the composition of NKRI sovereignty of the people should be based on the values of divinity, humanity, unity, deliberation and justice. Therefore, Indonesian democracy is not a liberal democracy nor a totalitarian democracy, as it relates thoroughly to the principles of Pancasila. This ethical orientation (wisdom) is brought to life through the power of rationality, conscientious wisdom, and a justice commitment that can present a positive tolerance and synthesis while preventing power from being controlled by "majorocracy" and "minorocracy".

In a deliberative democracy, a political decision is said to be true if it meets at least four conditions; a). Based on the principle of rationality and justice not only on the basis of ideological subjectivity and interests b). Dedicated to the interests of many people not for the benefit of individuals or groups c). Far-fore oriented, not for short-term interests through destructive transactional accommodation (negative tolerance) d). It is impartial, involving and considering all parties (the smallest minority) in an inclusive manner, which can counteract the dictates of the ruling elite and businessmen's minorities and majority claims.

In a deliberative democracy, a majority vote is received within the minimum conditions of democracy, which must still be optimized through the widespread participation and approval of all powers in an inclusive way. This widespread participation and agreement is achieved through quality persuasion, compromise and consensus by requiring a collective mentality with the guidance of wisdom, thereby enabling any power to feel belonging, loyal and responsible for all political decisions. On that basis, voting should be placed as a last effort, and it must still uphold the spirit of mutual family kinship. In a deliberative democracy, freedom loses its substantive meaning insofar as it is not accompanied by equality and kinship (kinship). The equality and spirit of kinship of different nationalist clusters is strengthened through the glorification of the values of justice.

After the amendment of the UUD 1945, according to Hamdan Zoelva, even though the normative amendments to the UUD 1945 dictate that a decision should be made by majority vote (Article 2 para (3) of the UUD 1945), but in practice every decision usually always prioritizes discussion prior to the vote. This means that even if structurally the amendment of the 1945 Constitution does not have a strong reference to the tradition, but procedurally the tradition remains preserved in practice as the main procedure in the Indonesian state administration system [3].

The realization of democracy in Indonesia after the amendment of the 1945 Constitution is a deliberative democracy as stipulated in the fourth precepts of Pancasila. It should be a tool for strengthening the sovereignty of the people based on a united states (which overcomes individual and group) and welfare state (oriented social justice), although its practice is hindered by cultural, institutional and structural barriers [9].

At a cultural level, politics as a technique progresses, on the other hand politics as ethics setbacks. The Hardware (democratic procedure) looks relatively more democratic; but its software (democratic culture) still nepotis-feudalistic. The expansion of political participation coincided with the expansion of corruption. At the institutional level, the design of democratic institutions places too much emphasis on allocative power (source of funds), rather than authoritative forces (human capacity). A capital-intensive democracy increases the cost of power, resulting in a high cost economy and a corrupt practice. Jimly Asshiddiqie, Chairman of the Election Organizing Committee (DKPP), described that money politics practiced in Election 2014 is the most 'massive' in the history of elections in Indonesia. Currently the behavior of money politics is more open and no longer closed as in the past [19]. The high cost of regional head election is believed to be the main cause of corruption [20].

At the structural level, the tendency to adopt "liberal" democratic models without adjusting to the conditions of Indonesian society can actually undermine democracy. While democracy requires equality and prosperity, our democratic design choices are often widening inequality and injustice. The fourth precept, which is democratic life led by wisdom of thoughts in deliberation amongst representatives of the people, is the character and the unique value of this nation that is togetherness and put forward deliberation in determining something for the common good. However, after the amendment of the 1945 Constitution many provisions can be used as a reference to claim that the UUD 1945 applies the principle of majority vote in decision making. Article 3 Paragraph (3), Article 6A Paragraph (3) and (4), Article 7B Paragraph (3) and Paragraph (7), Article 37 Paragraph (4) are some articles which can be mentioned as the application of the principle of majority vote. Therefore, it is irrefutable that the 1945 Constitution embraces the principle of majority vote as a procedural principle for the implementation of people's sovereignty [21]. 
Reformasi is directed more towards the aim of the state to realize democracy, and not to realize people's welfare [22]. In reality (das sein), our democratic system high cost democracy, high cost politics. According to Darwin as quoted by Kaelan democracy post-reformasi deficit, that is if the acquisition or benefit received by society with the presence of democracy, lower than the cost of democracy both in the financial sense issued and borne by the people, and the state to hold the democracy party, electing members of the legislature, the election of the President, the election of the Governor, the Regent / Mayor, Kades to Kadus. From here the roots of corruption have trapped the Governor and the Regent become prisoners. Based on Kompas notes, during 2004-2017 there were 78 heads of regions involved in corruption cases, 18 Governors and 60 Regents / Mayors. In addition, costs in a non-material sense, such as violence, primordial fanaticism, physical destruction, the decline of national unity and the lack of harmony and social cohesion [22].

It is said by the jurist Sudjito that the fourth principle of Pancasila implies the concept that the people or the people's representatives in exercising their powers must be led by wisdom, with full responsibility, vertically to God Almighty and horizontally to all Indonesian people, and not once on the basis of force or formal legality [23]. A philosophical wisdom will arise when people love the truth. The closer a man to the source of absolute truth, which is God Almighty, then he will be more wise. The popular concept of Pancasila thus matches the theistic character of the holistic paradigm of law.

In the implementation is that religious values are dynamic, people with mental intelligence and rational mind will be dynamic because they pay attention to the human aspects of their lives. Thus the cultural deity is a sacred dogma that must be the guide for the Indonesian in managing the natural, economic, political, or cultural resources in this country. Indonesian people are human beings who respect, love, and help each other because of the consciousness of a cultured God. The cultural deity is not the same as making God a living being. The cultural deity is, making God with all his character life in everyday life. This is called the dynamic deity, cultivated deities, and unselfish religions.

\section{CONCLUSION}

The formulation of the idea of democracy in Indonesia is a religious democracy, the democracy of people who are believe in God. As mentioned in the Preamble of the 1945 Constitution which has been agreed and ratified in the Preparatory Committee of Indonesian Independence Committee (PPKI) dated August 18, 1945. The democracy of Pancasila based on the values of divinity, humanity, unity, deliberation and justice. Therefore, Indonesian democracy is not a liberal democracy nor a totalitarian democracy, as it relates thoroughly to the principles of Pancasila. The closer a man to the source of absolute truth which is the God Almighty, then he will be more wise. And the root of wisdom is musyawarah ( $r a$ 'sul hikmah al-masyurah). The realization of democracy in Indonesia after the amendment of the 1945 Constitution is deliberative democracy as stipulated in the fourth precepts of Pancasila, in practice impeded by cultural, structural and institutional barriers.

\section{REFERENCES}

[1] Absori, Kata Pengantar Hukum Profetik : kritik terhadap Paradigma hukum Non- Sistemik, Yogyakarta : GENTA Publishing, 2015.

[2] Absori, Prosiding Seminar Nasional Universitas Muhammadiyah Surakarta, Epistimologi Ilmu Hukum Transendental dan implementasinya dalam Pengembangan Program Doktor Ilmu Hukum, 11 April 2015, ISBN 978-602-72446-0-3.

[3] A.F. Azhari, Tafsir Konstitusi Pergulatan Mewujudkan Demokrasi di Indonesia, Yogyakarta : GENTA Publishing, 2017.

[4] http://www.uiah.fi/projects/metodi/178.htm

[5] Absori, Pemikiran Hukum Transendental dalam Konteks Pengembangan Ilmu Hukum Indonesia dalam Transendensi Hukum Prospek dan Implementasi. Yogyakarta : GENTA Publishing, 2017, hal. 15.

[6] Kuntowijoyo, Islam sebagai Ilmu Epistemologi, Metodologi dan Etika, Yogyakarta : Tiara Wacana, 2007.

[7] F. Jonher, "Pancasila: 5 Ways of Life for Indonesian People," International Journal of Multidisciplinary Approach, vol. 05, pp. 22, 2018 .

[8] Absori, Cita Hukum Pancasila Ragam Paradigma Hukum Berkepribadian Indonesia, Solo : Pustaka Iltizam, 2016.

[9] Y. Latif, Negara Paripurna Historisitas, Rasionalitas dan aktualitas Pancasila. Jakarta: Gramedia Pustaka Utama, 2012.

[10] N. Huda, Ilmu Negara, Jakarta : Rajawali Pers, 2013.

[11] A.S. Maarif, Islam dan Politik di Indonesia pada Masa Demokrasi Terpimpin (1959-1965, Yogyakarta: IAIN Sunan Kalijaga Press, 1988.

[12] N. Madjid, Islam Kemodernan dan Keindonesiaan, Bandung : Mizan, 1987.

[13] Risalah Sidang BPUPKI dan PPKI 28 Mei 1945-22 Agustus 1945, Jakarta : Sekretariat Negara Republik Indonesia, 1998.

[14] G.S. Satya and J.A. Putra, "Actualization Pancasila Indonesia Persepctive As Legal Reform Law Progressive,” International Journal of Business, Economics and Law, vol. 8, pp. 1, 2015.

[15] A. Alkostar, Hukum progresif untuk Mewujudkan Keadilan substantive dalam Bingkai Nilai-Nilai Pancasila, dalam Prosiding Sarasehan Nasional “ Implementasi Nilai-Nilai Pancasila dalam Menegakkan Konstitusionalitas Indonesia, Jakarta: kerjasama UGM dan Sekjen MK, 2011, hal. 205, Baca Kompas, Hukum Untuk Kemanusiaan, 22 November 2017.

[16] L. Trijono, Kepastian Hukum dan Demokrasi, Kompas, 22 November 2017.

[17] N. Syam, Pancasila sebagai living Ideology. Makalah Kongres Pancasila III. UNAIR. 30 Mei-1 Juni 2011

[18] A.B. Nasution, Pikiran dan Gagasan Demokrasi Konstitusional. Jakarta Kompas Media Nusantara, 2011.

[19] E.Aspinall and M. Sukmajati (ed), Politik Uang di Indonesia Patronase dan Klientelisme pada Pemilu Legislatif 2014, Yogyakarta : PolGov.

[20] D. Supriyanto, Korupsi dan Mahar Pencalonan, Kompas 9 Oktober 2017.

[21] K. Fahmi, Pemilihan Umum dan Kedaulatan Rakyat, Jakarta : Raja Grafindo Persada, 2012.

[22] Kaelan, Fungsi Pancasila sebagai Paradigma Hukum dalam Penegakan Konstitusionalitas Indonesia, Prosiding Sarasehan Nasional “ Implementasi Nilai-Nilai Pancasila dalam Menegakkan Konstitusionalitas Indonesia, Jakarta: kerjasama UGM dan Sekjen MK, 2011.

[23] Sudjito, Hukum Progresif untuk Mewujudkan Keadilan Substantif dalam Bingkai Nilai-Nilai Pancasila, dalam Prosiding Implementasi NilaiNilai Pancasila dalam Menegakkan Konstitusionalitas Pancasial, kerjasama UGM dan Sekjen MK, 2011. 